\section{Biodegradation of Acid Scarlet 3R by a New Salt-tolerant Strain Alcaligenes faecalis LJ-3: Character, Enzyme and Kinetics Analysis}

\author{
X. Y. Song, F. J. Liu, H. B. Zhou, ${ }^{*}$ and H. L. Yang" \\ School of Life \& Environmental Science, Wenzhou University, \\ Chashan University Town, Wenzhou 325035, China
}

\author{
\begin{tabular}{|c|c|c|} 
EY \\
This work is licensed under a \\
Creative Commons Attribution 4.0 \\
International License
\end{tabular} \\ doi: 10.15255/CABEQ.2018.1410 \\ Original scientific paper \\ Received: June 18, 2018 \\ Accepted: September 24, 2018
}

\begin{abstract}
Alcaligenes faecalis LJ-3 is highly efficient in degrading various azo dyes (100 mg L-1). Almost $100 \%$ degradation was observed within $16 \mathrm{~h}$ at the initial Acid Scarlet 3R concentrations of $1000 \mathrm{mg} \mathrm{L}^{-1}$ under the optimal conditions, which were: $1 \mathrm{~g}$ dextrin $\mathrm{L}^{-1}, 3$ $\mathrm{g}$ yeast extract $\mathrm{L}^{-1}, \mathrm{NaCl} \leq 30 \mathrm{~g} \mathrm{~L}^{-1}, \mathrm{pH} 8.0$ and $35-45^{\circ} \mathrm{C}$. Azoreductase, laccase and NADH-DCIP (nicotinamide adenine dinucleotide-dichlorophenol indophenols) reductase were induced during the degradation of Acid Scarlet 3R. Kinetics study of degradation experiments approximated the first-order reaction. The maximum rate $\left(V_{\max }\right)$ and substrate affinity constant $\left(K_{\mathrm{s}}\right)$ were found to be $115.90 \mathrm{mg} \mathrm{L}^{-1} \mathrm{~h}^{-1}$ and $1193.23 \mathrm{mg} \mathrm{L}^{-1}$, respectively, using Michaelis-Menten kinetics. This work provides new data characterizing Acid Scarlet 3R degradation by bacteria, as well as practical application potential in biological treatment of industrial effluents containing various azo dyes.
\end{abstract}

Keywords:

Alcaligenes faecalis LJ-3, degradation, Acid Scarlet 3R, enzyme, kinetics

\section{Introduction}

It is well known that the demographic expansion, economic development, and industrialization have continuously generated increasing water pollution, which not only poses a serious threat to the survival of aquatic organisms, but also causes human health risks ${ }^{1}$.

Azo dyes, aromatic and/or heterocyclic compounds characterized by the presence of one or more azo groups $(-\mathrm{N}=\mathrm{N}-)$, are the largest chemical class of synthetic dyes and pigments, representing about $70 \%$ of the synthetic dyes used in textile, leather, plastic, cosmetic, and food industries ${ }^{2}$, and $10-15 \%$ azo dyes are lost in aqueous effluents during coloration processes. Most azo dyes are toxic and/or mutagenic to living organisms, and highly stable to light and oxygen due to their complex chemical structures ${ }^{3}$. Therefore, various technologies have been developed to treat azo dyes containing effluents. Compared with physicochemical processes such as adsorption, membrane separation, ion-exchange, coagulation, and oxidation, biological methods are better alternatives due to their lower cost, higher efficiency and less secondary pollution $^{4,5}$.

"Corresponding author: H. L. Yang, Phone: +86-577-86691013. Fax: +86-577-86689257.

E-mail: yangh199@163.com; H. B. Zhou, Email: zhb@wzu.edu.cn
Hence, increasing research has been performed to screen microbes for azo dyes degradation in the last decades. Some bacterial, yeast, fungal, and algal species such as Lactobacillus paracase CL1107 ${ }^{6}$ and Scheffersomyces spartinae TLHS-SF1 ${ }^{7}$, etc., have been confirmed to be able to decolorize azo dyes through degradation or adsorption. In particular, bacteria have been proved to be the most promising due to their extensive distribution, strong adaptability, short life cycle, less secondary waste, and high activity ${ }^{8}$. Bacterial consortium AR1 could completely decolorize $100 \mathrm{mg} \mathrm{L}^{-1}$ of Reactive Red 195 within $14 \mathrm{~h}^{9}$. Chen et al. developed a thermophilic microflora which biodegraded $97 \%$ of Direct Black G $\left(600 \mathrm{mg} \mathrm{L}^{-1}\right)$ within $8 \mathrm{~h}^{10}$. Furthermore, much effort has been devoted to isolate bacterial strains capable of efficiently degrading azo dyes. Garg et al. isolated Pseudomonas putida SKG-1 (MTCC10510) that was capable of decolorizing monoazo dye Orange II efficiently ${ }^{11}$. Guadie et al. isolated and characterized Reactive Red 239 decolorization strain (Bacillus sp. strain CH12) from alkaline lake ${ }^{12}$. Bacillus sp. YZU1 showed approximately $95 \%$ decolorization of Reactive Black 5 $\left(100 \mathrm{mg} \mathrm{L}^{-1}\right)$ within $120 \mathrm{~h}^{13}$. Aeromonas sp. strain DH-6 was also observed to have a remarkable ability to decolorize methyl orange, nearly $100 \%$ decolorization at concentration of $100 \mathrm{mg} \mathrm{L}^{-1}$ in $12 \mathrm{~h}^{14}$.

Azo dye decolorization/degradation varies with varying strains and cultural conditions. Acid Scarlet $3 \mathrm{R}$ is an electron-deficient xenobiotic compound 
because of its azo linkage and sulphonic $\left(\mathrm{SO}_{3}^{-}\right)$ groups, which generate an electron deficiency and make the dye less susceptible to degradation by microorganisms. In the present study, a new strain, $\mathrm{Al}$ caligenes faecalis LJ-3, capable of decomposing Acid Scarlet 3R, was successfully isolated from textile dye contaminated soil of a printing and dyeing plant. The effects of different parameters on degradation were investigated. In addition, the pertinent enzymes and degradation kinetics were also analyzed to explore the degradation mechanism.

\section{Materials and methods}

\section{Microorganism, media, dyes, and chemicals}

Alcaligenes faecalis LJ-3 (CGMCC14108) was screened by the Laboratory of Fermentation, Wenzhou University (Wenzhou, China) and collected in China General Microbiological Culture Collection Center (Beijing, China).

Luria-Bertani medium (LB, $\mathrm{g} \mathrm{L}^{-1}$ ): peptone 10 , yeast extract 5 and $\mathrm{NaCl} 5$; Acclimation medium (g L $\left.{ }^{-1}\right)$ : Glucose 1, $\left(\mathrm{NH}_{4}\right) \mathrm{NO}_{3}$ 2.0, $\mathrm{Na}_{2} \mathrm{HPO}_{4} 0.5$, $\mathrm{KH}_{2} \mathrm{PO}_{4} 0.5, \mathrm{MgSO}_{4} \cdot 7 \mathrm{H}_{2} \mathrm{O} 0.2$, and $\mathrm{CaCl}_{2} \cdot 2 \mathrm{H}_{2} \mathrm{O}$ 0.1 ; Basal medium $\left(\mathrm{g} \mathrm{L} \mathrm{L}^{-1}\right): \mathrm{Na}_{2} \mathrm{HPO}_{4} 1.0, \mathrm{KH}_{2} \mathrm{PO}_{4}$ 3.0, $\mathrm{NaCl} 0.5, \mathrm{MgSO}_{4} \cdot 7 \mathrm{H}_{2} \mathrm{O} 0.5$ and $\mathrm{CaCl}_{2} \cdot 2 \mathrm{H}_{2} \mathrm{O}$ 0.025 .

ABTS (2,2-Azinobis(3-ethylbenzothiazolin-6sulfonic acid)), DCIP (2,6-Dichloroindophenol sodium), 3,4-Dimethoxybenzyl alcohol and NADH (reduced form of nicotinamide adenine dinucleotide) were purchased from Sigma-Aldrich Co. (USA). Azo dyes (Acid Scarlet 3R, Methyl Orange, Amino Black 10B, Acid Black 210, Brilliant Scarlet GR, Acid Red 88, Reactive Brilliant Red X-3B, Amaranth, Acid Orange G and Direct Red 80) and other reagents were obtained from Sinopharm Chemical Reagent Company (China). All chemicals used were of the highest purity available and of analytical grade.

\section{Enrichment and isolation of azo dye-degrading bacteria}

The textile dye contaminated soil used for the isolation of bacteria was collected from Lucheng printing and dyeing plant, Wenzhou, China. Ten grams of sludge samples were added into $250-\mathrm{mL}$ Erlenmeyer flasks containing $100 \mathrm{~mL}$ of LB medium, and the flasks were incubated at $37^{\circ} \mathrm{C}$ for $16 \mathrm{~h}$. Then, $10 \mathrm{~mL}$ of each culture was inoculated into $100 \mathrm{~mL}$ of acclimation medium containing $50 \mathrm{mg} \mathrm{L}^{-1}$ Acid Scarlet 3R, and incubated under the same conditions described above. Once decolorization was observed, $10 \mathrm{~mL}$ of culture was transferred to $100 \mathrm{~mL}$ fresh acclimation medium containing 100 $\mathrm{mg} \mathrm{L}^{-1}$ Acid Scarlet 3R. With each successive transfer, the concentration of Acid Scarlet 3R was gradually increased to $200 \mathrm{mg} \mathrm{L}^{-1}$. After the fifth enrichment transfer, each culture was serially diluted with sterile saline and spread on LB plates containing $100 \mathrm{mg} \mathrm{L}^{-1}$ Acid Scarlet 3R for the isolation of single colonies. After being incubated under anoxic conditions at $37^{\circ} \mathrm{C}$ for $48 \mathrm{~h}$, the bacterial colonies were screened according to the ability to form a clear zone on the plate. The bacteria showing higher zones of decolorization were isolated and further purified by streaking plate method on LB plates containing $100 \mathrm{mg} \mathrm{L}^{-1}$ Acid Scarlet 3R. Pure culture was maintained on LB agar slants, stored at $4{ }^{\circ} \mathrm{C}$, and sub-cultured monthly.

\section{Identification of the isolated strain by $16 \mathrm{~S}$ rDNA sequencing}

The bacterial strain with the highest degradation ability of Acid Scarlet 3R was named LJ-3 and selected for further study. The 16S rDNA sequencing of strain LJ-3 was carried out at Sangon Biotech (Shanghai) Co Ltd., China. Briefly, the isolated genomic DNA was used as a template to amplify the 16S rDNA gene by PCR with the universal primers: 27F (5'-AGAGTTTGATCCTGGCTCAG-3') and 1492R (5'-GGTTACCTTGTTACGACTT-3'). The PCR was run for 30 cycles with the following thermal conditions: $45 \mathrm{~s}$ of denaturation at $94{ }^{\circ} \mathrm{C}, 45 \mathrm{~s}$ of primer annealing at $55{ }^{\circ} \mathrm{C}$, and $1 \mathrm{~min}$ of extension at $72{ }^{\circ} \mathrm{C}$. The final cycle included an extension of $10 \mathrm{~min}$ at $72{ }^{\circ} \mathrm{C}$. The resulting sequence (GenBank accession No. MG574872) was compared with known sequences in the GenBank database by BLAST.

\section{Degradation experiments}

Degradation experiments were carried out in 250-mL Erlenmeyer flasks containing $100 \mathrm{~mL}$ sterilized medium supplemented with azo dye, and the inoculation size $\left(\mathrm{OD}_{600} 0.8\right)$ was $2 \%(\mathrm{v} / \mathrm{v})$. To characterize the degradation efficiency of strain LJ-3, the effects of static anoxic/shaking conditions (160 rpm), carbon sources (glucose, maltose, sucrose, lactose, dextrin, fructose, and xylose), nitrogen sources (yeast extract, beef extract, peptone, urea, glycine, $\mathrm{NH}_{4} \mathrm{NO}_{3}$, and $\mathrm{NaNO}_{3}$ ), initial $\mathrm{pH}(4.0,5.0$, $6.0,7.0,8.0,9.0,10.0,11.0,12.0)$, incubation temperature $\left(15,20,25,30,35,40,45,50^{\circ} \mathrm{C}\right)$, and salinity $\left(5,10,15,20,25,30,50,80 \mathrm{~g} \mathrm{~L}^{-1} \mathrm{NaCl}\right)$ on the degradation of $100 \mathrm{mg} \mathrm{L}^{-1}$ Acid Scarlet 3R were individually monitored. To find out maximum dye degrading ability of strain LJ-3, different concentrations of Acid Scarlet 3R (100, 200, 400, 600, 800, $1000,1500,2000 \mathrm{mg} \mathrm{L}^{-1}$ ) were respectively tested. To determine the degradation activity of strain LJ-3 
on other azo dyes, the cells were respectively incubated in the media containing $100 \mathrm{mg} \mathrm{L}^{-1}$ of different azo dyes.

Concentration of azo dyes in supernatant withdrawn at different time intervals was analyzed at the maximum absorption wavelength (Table 1) with a UV-1810 spectrophotometer (Puxi General Instrument Co., Ltd., China) after centrifugation at 4,000 $\mathrm{g}$ for $10 \mathrm{~min}$. The percentage degradation was calculated according to the following formula (1).

$$
\text { Degradation }(\%)=\left(A_{0}-A_{1}\right) / A_{0} \cdot 100
$$

where $A_{0}$ and $A_{1}$ is the absorbance of the dye at initial and different reaction times, respectively.

\section{Enzyme analysis}

The LJ-3 cells were harvested by centrifugation at $12000 \mathrm{~g}$ for $10 \mathrm{~min}$. The harvested cells were then suspended in $100 \mathrm{mM}$ sodium phosphate buffer (pH 7.4) and sonicated at $4{ }^{\circ} \mathrm{C}$ based on a 100 amplitude output, 99 strokes of $7 \mathrm{~s}$, each at $3 \mathrm{~s}$ intervals. The supernatant was collected by centrifugation $\left(4{ }^{\circ} \mathrm{C}\right.$, at $12000 \mathrm{~g}$ for $\left.15 \mathrm{~min}\right)$ and used for enzyme analysis.

The activities of azoreductase, laccase, veratryl alcohol oxidase, and NADH-DCIP reductase were assayed spectrophotometrically by reference to the methods of Shah et $a l^{15}$. Manganese peroxidase activity was measured by reference to the method of Bilal and Asgher ${ }^{16}$. Protein concentration was determined by the Lowry method using bovine serum albumin as the standard ${ }^{17}$. One unit of enzyme activity was defined as the amount of enzyme required to reduce or oxidize $1 \mu \mathrm{g}$ (or $\mu \mathrm{M}$ ) of substrate per minute per $\mathrm{mg}$ of protein.

\section{Kinetics study}

To determine the order of the degradation reaction of $A$. faecalis LJ-3, the rate constants of degradation reaction and coefficients of least square method analysis were calculated. The zero-, firstand second-order reaction kinetics were respectively expressed as equations (2)-(4) below:

$$
\begin{aligned}
{[D]_{t} } & =[D]_{0}-k_{0} t \\
\ln [D]_{t} & =\ln [D]_{0}-k_{1} t \\
1 /[D]_{t} & =1 /[D]_{0}+k_{2} t
\end{aligned}
$$

where $[D]_{0}$ and $[D]_{t}$ are the concentrations of dye at reaction time 0 and $t$, respectively. $k_{0}, k_{1}$ and $k_{2}$ are the kinetic rate constants of zero-, first-, second-order reaction kinetics, respectively. $t$ is the reaction time.
Michaelis-Menten model (equation 5) was used to fit the relationship between the degradation rate and initial dye concentration.

$$
V=\frac{V_{\max }[D]}{K_{\mathrm{s}}+[D]}
$$

where $[D]\left(\mathrm{mg} \mathrm{L}^{-1}\right), V_{\max }\left(\mathrm{mg} \mathrm{L}^{-1} \mathrm{~h}^{-1}\right)$ and $K_{\mathrm{s}}\left(\mathrm{mg} \mathrm{L}^{-1}\right)$ are dye concentration, maximum dye degradation rate and substrate affinity constant, respectively.

\section{Results and discussion}

\section{Identification and azo dye biodegradation of strain LJ-3}

In the present study, a bacterial strain (named LJ-3), capable of decolorizing Acid Scarlet 3R (100 $\mathrm{mg} \mathrm{L}^{-1}$ ) on solid agar plate, was successfully isolated from textile dye contaminated soil of a printing and dyeing plant in Wenzhou, China. It was Gram-negative, and the colony on LB plate was smooth, lustrous, light brown and regular on the edge. The 16S rDNA gene sequence $(1337 \mathrm{bp})$ of strain LJ-3 was determined and deposited in GenBank database under the accession number MG574872. Strain LJ-3 was identified as A. faecalis based on the sequence similarity analysis, which exhibited $100 \%$ homology to A. faecalis Fa1.3 (accession number KF383272).

It had been reported that some isolates belonging to A. faecalis could biodegrade and detoxify a series of xenobiotic/recalcitrant compounds such as endosulfan ${ }^{18}$, nicosulfuron ${ }^{19}$ and ochratoxin $\mathrm{A}^{20}$. Strain A. faecalis PMS-1 could also decolorize Reactive Orange $13^{15}$. As shown in Table 1, strain $A$. faecalis LJ-3 could efficiently biodegrade a wide variety of azo dyes, including Acid Scarlet 3R, Methyl Orange, Amino Black 10B, Acid Black 210, Brilliant Scarlet GR, Acid Red 88, Reactive Brilliant Red X-3B, Amaranth, Acid Orange G, and Direct Red 80. Except for Acid Black 210, the highest degradations of the other nine dyes by strain $A$. faecalis LJ-3 were more than $92 \%$ within 4-24 h. Obviously, strain $A$. faecalis LJ-3 has great potential in treating industrial effluents containing azo dyes due to the high dye adaptability and short removal time.

\section{Effects of parameters on biodegradation of Acid Scarlet 3R by strain LJ-3}

As shown in Fig. 1, $96.94 \%$ degradation of Acid Scarlet 3R by strain A. faecalis LJ-3 was determined under static anoxic conditions, whereas only $3.77 \%$ degradation was observed under shaking conditions at $160 \mathrm{rpm}$ after $8 \mathrm{~h}$ of incubation. Similar results were also reported previously on 
Table 1 -Degradation of various azo dyes $\left(100 \mathrm{mg} \mathrm{L}^{-1}\right)$ by A. faecalis LJ-3

\begin{tabular}{l|l|l|l|c|c|c}
\hline \multicolumn{2}{l|}{ Azo dyes } & $\begin{array}{c}\text { Before } \\
\text { degradation }\end{array}$ & $\begin{array}{c}\text { After } \\
\text { degradation }\end{array}$ & $\begin{array}{c}\text { Maximum } \\
\text { wavelength } \\
(\mathrm{nm})\end{array}$ & $\begin{array}{c}\text { Degradation } \\
(\%)\end{array}$ & $\begin{array}{c}\text { Time } \\
(\mathrm{h})\end{array}$ \\
\hline
\end{tabular}

Acid

Scarlet 3R

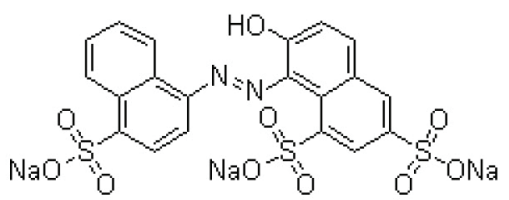<smiles>CN(C)c1ccc(/N=N/c2ccc(S(=O)(=O)O[Na])cc2)cc1</smiles>

Methyl

Orange<smiles>Nc1c(N=Nc2ccc([N+](=O)[O-])cc2)c(S(=O)(=O)O[Na])cc2cc(S(=O)(=O)[O-])c(N=Nc3ccccc3)c(O)c12</smiles><smiles>[Z20]OS(=O)(=O)c1cc2cc(N=Nc3ccc([N+](=O)[O-])cc3)c(N=Nc3ccc(NS(=O)(=O)Nc4ccc(N=Nc5ccc(N)cc5N)cc4)cc3)c(O)c2c(N)c1S(=O)(=O)O</smiles>

Black

210

Amino

Black 10B
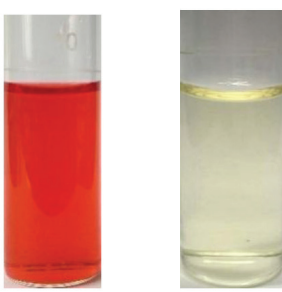

508

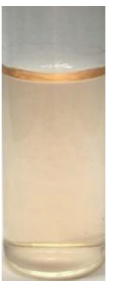

462

$95.51 \quad 6$

618

92.62

12
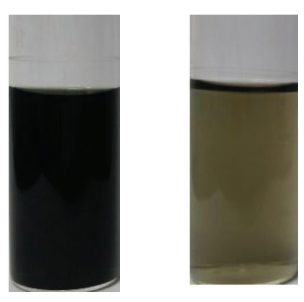

606

85.3 24<smiles></smiles>
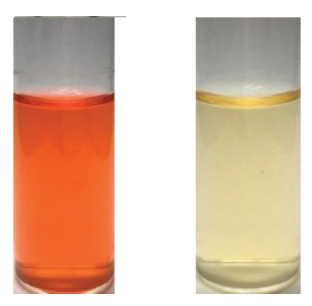

Scarlet GR 


\begin{tabular}{c|c|c|c|c|c|c}
\hline \multicolumn{2}{|c|}{ Azo dyes } & $\begin{array}{c}\text { Before } \\
\text { degradation }\end{array}$ & $\begin{array}{c}\text { After } \\
\text { degradation }\end{array}$ & $\begin{array}{c}\text { Maximum } \\
\text { wavelength } \\
(\mathrm{nm})\end{array}$ & $\begin{array}{c}\text { Degradation } \\
(\%)\end{array}$ & $\begin{array}{c}\text { Time } \\
(\mathrm{h})\end{array}$ \\
\hline
\end{tabular}

Acid Red

88<smiles>CS(=O)(=O)c1ccc(N=Nc2c(O)ccc3ccccc23)c2ccccc12</smiles>

Reactive

Brilliant

Red

X-3B

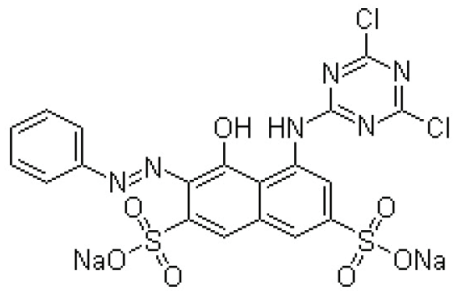

Amaranth<smiles>O=S(=O)(O[Na])c1ccc2c(N=Nc3ccc(S(=O)(=O)O[Na])c(O)c3[SH](=O)([O-])O)cccc2c1</smiles>

Acid

Orange $\mathrm{G}$<smiles>O=S(=O)([OH2+])c1cc(S(=O)(=O)O[18O])cc2ccc(O)c(N=Nc3ccccc3)c12</smiles>

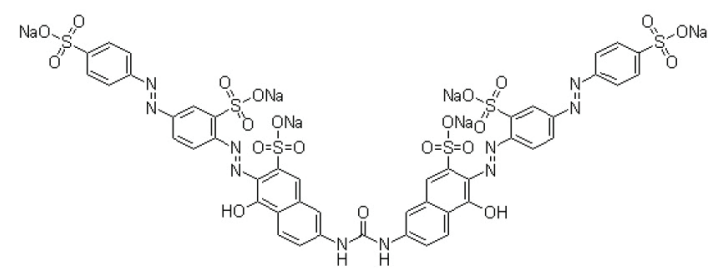

Direct Red

80
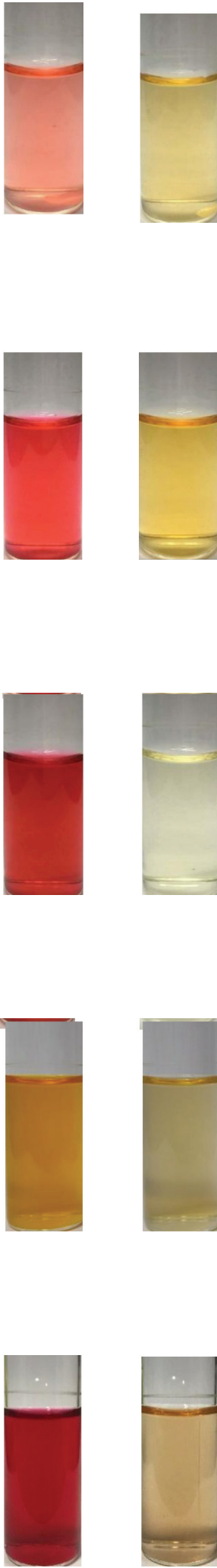


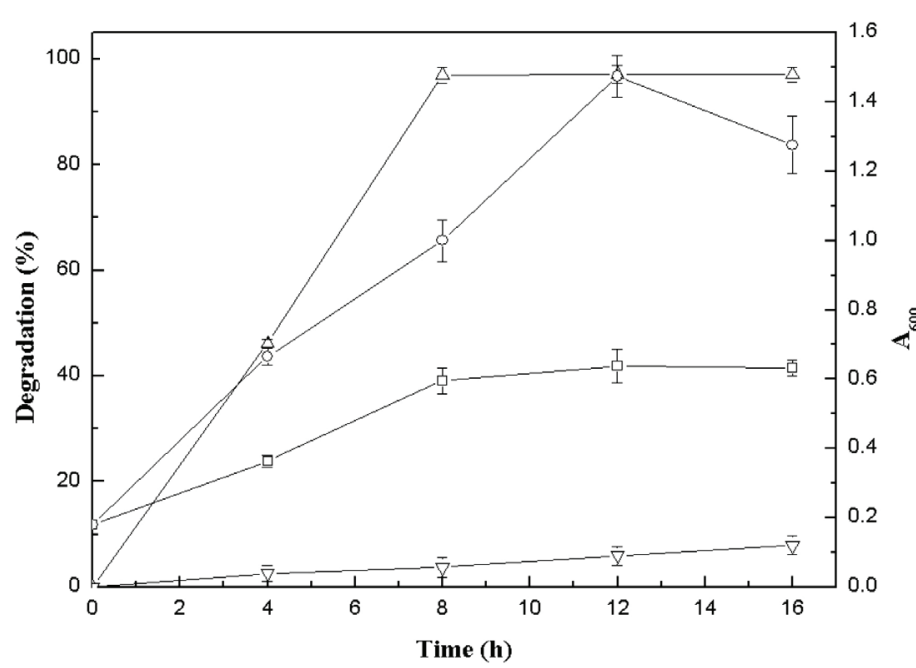

$-\triangle$ Degradation (Static) $\quad-\square-$ Growth(Static)

$-\nabla-$ Degradation (Shaking) $-\diamond-$ Growth(Shaking)

Fig. 1 - Effects of shaking $(160 \mathrm{rpm})$ and static anoxic conditions on the degradation of Acid Scarlet $3 R$ by A. faecalis $L J-3$ pure bacterial strains such as A. faecalis PMS-15, Pseudomonas sp. SUK $1^{21}$ and Micrococcus glutamicus NCIM-2168 22 . Because reduction is the basic mechanism of bacterial biodegradation, anaerobic or anoxic conditions are beneficial to the degradation of azo dyes by bacterial strain ${ }^{23}$.

Azo dye degradation by microbes generally requires supplement of carbon or nitrogen sources. Jain et al. suggested that glucose is the optimal carbon source for Reactive Violet 5R degradation by bacterial strains such as Bacillus sp. V1DMK and Lysinibacillus sp. V3DMK ${ }^{24}$. However, our results showed that, when dextrin was supplemented as a carbon source, the strain A. faecalis LJ-3 showed a faster removal of Acid Scarlet 3R (Fig. 2a). The results were supported by Mathew and Madamwar, who confirmed that soluble starch was the optimal carbon source for azo dye degradation by bacterial consortium SV5 ${ }^{25}$. The biodegradation increased with the increase in dextrin concentration from 0.1 to $1.0 \mathrm{~g} \mathrm{~L}^{-1}$, and reached $98.05 \%$ within $8 \mathrm{~h}$ (Fig. 2b).
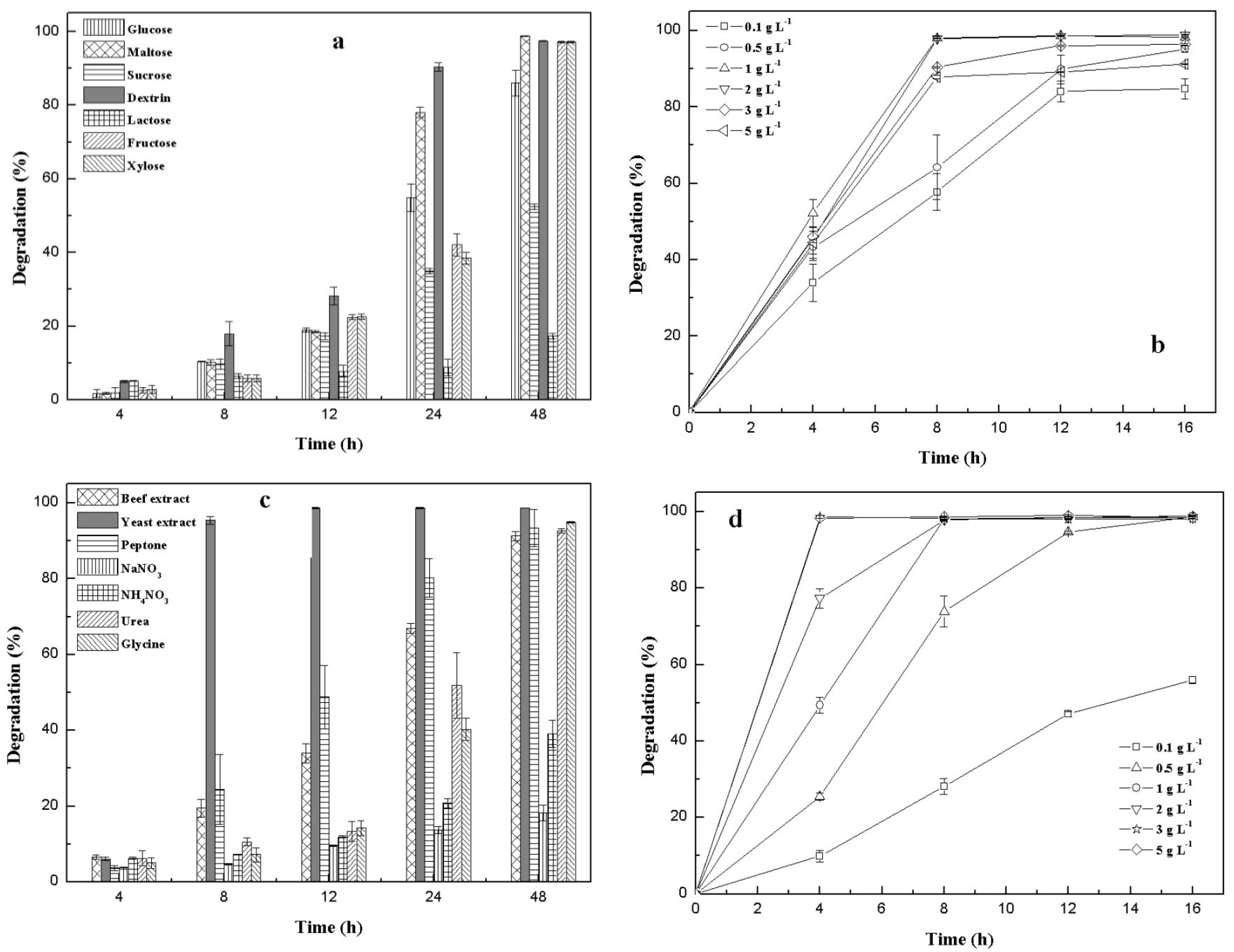

Fig. 2 - Effects of carbon sources (a), dextrin concentration (b), nitrogen sources (c), and yeast extract (d) on the degradation of Acid Scarlet $3 R$ by A. faecalis LJ-3 
Of all tested nitrogen sources in this work, glycine, $\mathrm{NH}_{4} \mathrm{NO}_{3}$ and $\mathrm{NaNO}_{3}$ exhibited less than $10 \%$ degradation of the dye within $8 \mathrm{~h}$, followed by urea, beef extract, and peptone with degradation of $10.61 \%, 19.52 \%$ and $24.41 \%$, respectively (Fig. $2 \mathrm{c})$. In accordance with the previous studies ${ }^{24,25}$, yeast extract showed best degradation efficiency $(95.42 \%)$ because yeast extract is helpful for NADH regeneration ${ }^{23}$ and stimulating for azoreductase activity ${ }^{26}$. The degradation reached $98.69 \%$ within $4 \mathrm{~h}$ when $3 \mathrm{~g} \mathrm{~L}^{-1}$ yeast extract was added, while the further increase in yeast extract concentration could not significantly enhance degradation efficiency (Fig. 2d).

Temperature and $\mathrm{pH}$-value are important parameters for azo dye biodegradation by bacteria. Strain A. faecalis LJ-3 could degrade Acid Scarlet $3 \mathrm{R}$ in the $\mathrm{pH}$ range of 5.0-10.0 with degradation above $80 \%$ within $16 \mathrm{~h}$, but the optimal degrading efficiency was found at $\mathrm{pH} 8.0$ with $97.49 \%$ degradation within $8 \mathrm{~h}$ (Fig. 3a). With an increase in tem- perature from 15 to $35^{\circ} \mathrm{C}$, the degradation increased from $7.12 \%$ to $97.38 \%$ within $8 \mathrm{~h}$, and similar degradation was observed at $40{ }^{\circ} \mathrm{C}$ and $45^{\circ} \mathrm{C}$, while the dye almost could not be degraded at $50{ }^{\circ} \mathrm{C}$ (Fig. $3 \mathrm{~b})$. The results suggest that the optimum temperature range for degradation was between $35{ }^{\circ} \mathrm{C}$ and $45^{\circ} \mathrm{C}$, which was in accordance with the conclusion of Pearce et al..$^{27}$

Generally, the high concentrations of salts existing in textile industrial effluents will affect the microbial growth and dye biodegradation efficiency by causing plasmolysis of cells ${ }^{7,13}$. As shown in Fig. $3 \mathrm{c}$, the degradation by $A$. faecalis $\mathrm{LJ}-3$ reached $93.64 \%$ within $16 \mathrm{~h}$ in the presence of $30 \mathrm{~g}$ $\mathrm{NaCl} \mathrm{L}{ }^{-1}$. However, there are negative effects on the degradation with further increased salinity, and lower than $57 \%$ and $14 \%$ degradation efficiency were observed within $16 \mathrm{~h}$ in $\mathrm{NaCl}$ concentrations of $50 \mathrm{~g} \mathrm{~L}^{-1}$ and $80 \mathrm{~g} \mathrm{~L}^{-1}$, respectively. Different strains show a wide range of salt tolerance. The maximum salt tolerance of Pseudomonas sp. ACT 1
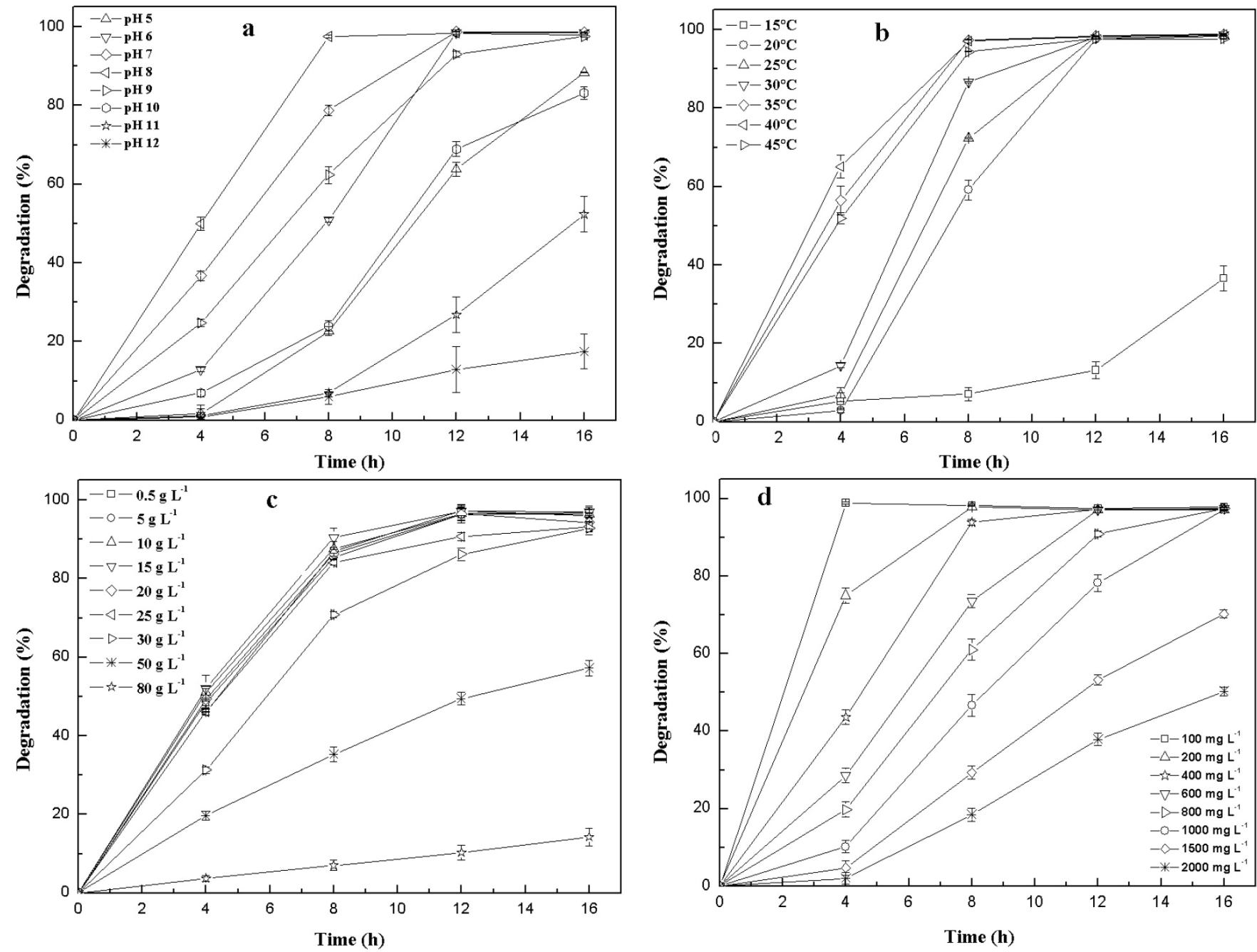

Fig. 3 - Effects of pH (a), temperature (b), salt concentration (c), and initial dye concentration (d) on the degradation of Acid Scarlet $3 R$ by $A$. faecalis $L J-3$ 
Table 2 -Comparison of azo dye removal efficiency of this study and other studies

\begin{tabular}{l|l|c|c|c|c}
\hline \multicolumn{1}{c}{ Microbial isolate } & \multicolumn{1}{c|}{ Azo dye } & Concentration $\left(\mathrm{mg} \mathrm{L}^{-1}\right)$ & Time $(\mathrm{h})$ & Degradation (\%) & Reference \\
\hline Scheffersomyces spartinae TLHS-SF1 & Acid Scarlet 3R & 100 & 16 & 80 & 7 \\
Pseudomonas putida SKG-1 & Orange II & 100 & 96 & 85.2 & 11 \\
Bacillus sp. strain CH12 & Reactive Red 239 & 100 & 24 & 95 & 12 \\
Bacillus sp. YZU1 & Reactive Black 5 & 100 & 120 & 95 & 13 \\
Aeromonas sp. DH-6 & Methyl Orange & 100 & 12 & Almost 100 & 14 \\
Alcaligenes faecalis PMS-1 & Reactive Orange 13 & 400 & 16 & Almost 100 & 15 \\
Brevibacillus laterosporus MTCC 2298 & Disperse Red 54 & 200 & 72 & 94 & 30 \\
Enterobacter sp. EC3 & Reactive Black 5 & 500 & 120 & 91.2 & 34 \\
Enterobacter aerogenes PP002 & Direct Green 28 & 100 & 168 & 99.23 & 35 \\
E. aerogenes PP002 & Direct Blue 71 & 100 & 168 & 99.0 & 35 \\
A. faecalis LJ-3 & Acid Scarlet 3R & 100 & 4 & 98.95 & This study \\
A. faecalis LJ-3 & Acid Scarlet 3R & 1000 & 16 & 99.17 & This study \\
\hline
\end{tabular}

in Congo Red biodegradation was $8 \mathrm{~g} \mathrm{NaCl} \mathrm{L}^{-1}$ after acclimatization ${ }^{28}$. Psychrobacter alimentarius KS23 and Staphylococcus equorum KS26, isolated from Arabian seawater sediment, could efficiently degrade Reactive Black 5 in the presence of $40 \mathrm{~g}$ $\mathrm{NaCl} \mathrm{L}{ }^{-1} .^{29}$ The result of this study showed that A. faecalis LJ-3 was salt-tolerant because of its good degradation efficiency at high salinity.

Dye concentration significantly influences degradation efficiency of microbes and faster degradation is achieved in lower dye concentrations. Almost $100 \%$ degradation was observed within $4 \mathrm{~h}$ at the initial Acid Scarlet 3R concentration of $100 \mathrm{mg} \mathrm{L}^{-1}$, $8 \mathrm{~h}$ at the initial concentration of $200 \mathrm{mg} \mathrm{L}^{-1}, 12 \mathrm{~h}$ at the initial concentrations of $400-600 \mathrm{mg} \mathrm{L}^{-1}$, and $16 \mathrm{~h}$ at the initial concentrations of $800-1000 \mathrm{mg} \mathrm{L}^{-1}$. Further increasing dye concentrations to 1500 and $2000 \mathrm{mg} \mathrm{L}^{-1}$, only $71.26 \%$ and $51.28 \%$ degradation, respectively, was determined after incubation for $16 \mathrm{~h}$ (Fig. 3d). Increasing the initial dye concentration decreased the degradation over the same time interval and inhibition was observed at high concentration. Similar results were also reported by Garg et al. ${ }^{11}$, Shah et al. ${ }^{15}$ and Kurade et al. ${ }^{30}$ due to the toxic effect of azo dyes on the degrading microorganisms and blockage of azoreductase active sites by complex dye molecules.

Table 2 summarizes some previous studies on azo dyes degradation. Compared with the reported strains, A. faecalis LJ-3 shows faster degradation rate and stronger tolerance to high concentrations of Acid Scarlet 3R.

\section{Enzyme analysis}

Enzyme catalysis is considered as the major mechanism in microbial degradation of azo dyes, and various oxidative and reductive enzymes like veratryl alcohol oxidase, laccase, manganese peroxidase, azoreductase and NADH-DCIP reductase were recorded in azo dye degrading microbes for decolorization/degradation of azo dyes ${ }^{15,30,31}$.

As shown in Table 3, azoreductase, laccase and NADH-DCIP reductase were determined in cells of A. faecalis LJ-3. As compared with that of control, activities of azoreductase, laccase and NADH-DCIP reductase in the dye degrading sample had increased 3.77-fold, 1.24-fold, and 3.13-fold, respectively. A similar inductive pattern of pertinent enzymes was also observed during degradation of azo dyes by Aeromonas sp. strain DH-6 ${ }^{14}$, M. glutamicus NCIM$2168^{22}$, Brevibacillus laterosporus ${ }^{30}$, Bacillus sp. strain UN2 $2^{32}$ and Morganella sp. HK-133. Furthermore, no dye was adsorbed on the cell pellets of $A$. faecalis LJ-3 (Fig. 4a), and UV-vis spectral scanning $(200-700 \mathrm{~nm})$ of supernatants displayed that

Table 3 - Enzyme activity in control A. faecalis LJ-3 cells (0 $h$ ) and the cell obtained after degradation of Acid Scarlet $3 R(4 h)$

\begin{tabular}{lcc}
\hline \multicolumn{1}{c|}{ Enzyme } & $\begin{array}{c}\text { Control cells } \\
(0 \mathrm{~h})\end{array}$ & $\begin{array}{c}\text { Cells obtained after } \\
\text { degradation }(4 \mathrm{~h})\end{array}$ \\
\hline Azo reductase $^{\mathrm{a}}$ & $4.33 \pm 0.220$ & $16.33 \pm 0.530^{* * *}$ \\
Laccase $^{\mathrm{b}}$ & $0.033 \pm 0.001$ & $0.041 \pm 0.001^{*}$ \\
NADH-DCIP reductase $^{\mathrm{c}}$ & $13.42 \pm 0.300$ & $42.02 \pm 0.531^{* *}$ \\
Veratryl alcohol oxidase & - & - \\
Manganese peroxidase & - & - \\
\hline
\end{tabular}

$* p<0.05, * * p<0.01, * * * p<0.001$

${ }^{\mathrm{a}} \mu \mathrm{g}$ of Acid Scarlet $3 \mathrm{R}$ reduced $\mathrm{min}^{-1} \mathrm{mg}$ protein ${ }^{-1}$.

${ }^{\mathrm{b}} \mu \mathrm{M}$ ABTS oxidized $\mathrm{min}^{-1} \mathrm{mg}$ protein ${ }^{-1}$.

${ }^{c} \mu \mathrm{g}$ DCIP reduced $\mathrm{min}^{-1} \mathrm{mg}$ protein ${ }^{-1}$. 

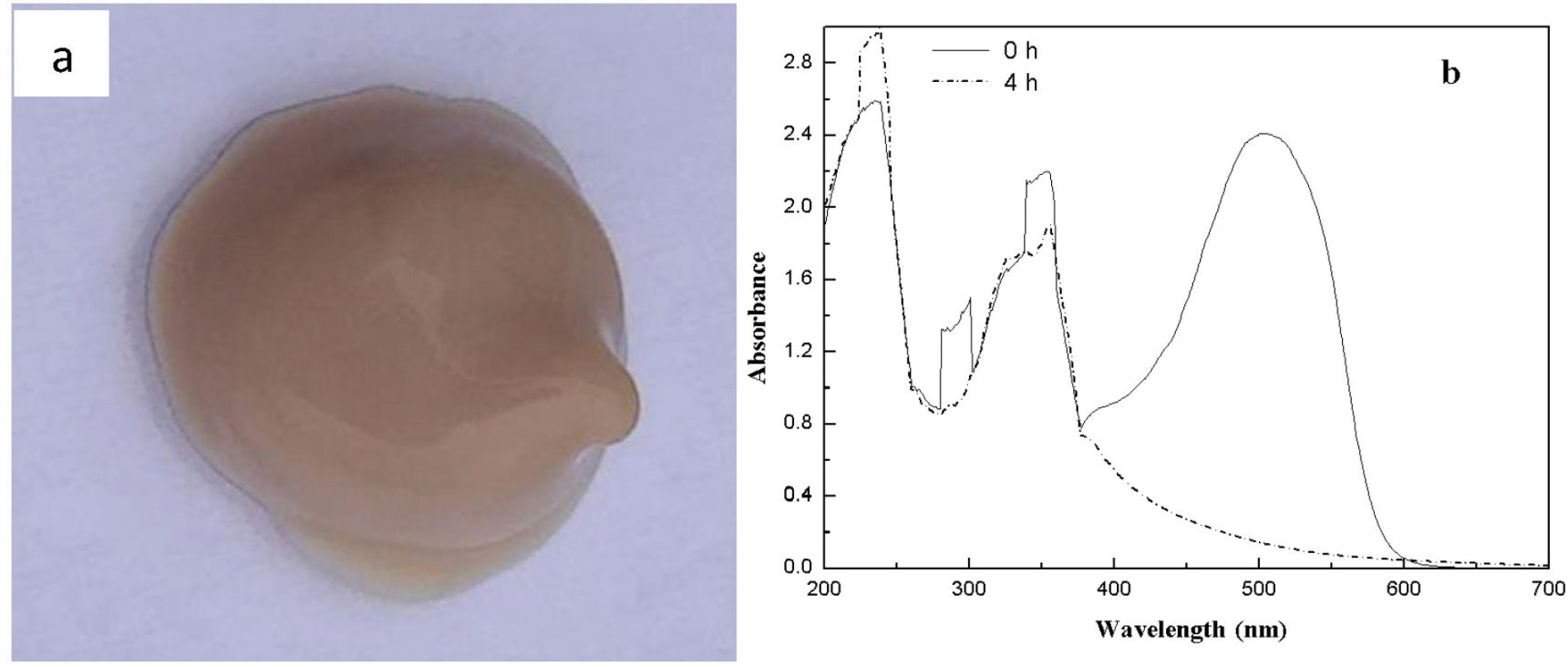

Fig. 4 - Cell pellets of A. faecalis LJ-3 after decolorization (a) and UV-vis spectra of Acid Scarlet $3 R$ before (0 h), and after (4 h) degradation (b)

the intensity at the maximum absorbance wavelength $(508 \mathrm{~nm})$ of Acid Scarlet 3R drastically decreased after degradation in $4 \mathrm{~h}$ (Fig. 4b), which indicated that the azo groups were destroyed ${ }^{7}$. From these results, it could be primarily speculated that A. faecalis LJ-3 degrades the azo dye via enzymatic mechanism, which supports the previous conclusion that azo dye degradation by bacteria is due to biodegradation, rather than surface adsorption ${ }^{34}$.

\section{Kinetics study}

The biodegradation kinetics is essential for reactor design to treat dye-containing effluents efficiently. Sudha et al. reported that the degradation of Direct Blue 71 and Direct Green 28 by Enterobacter aerogenes PP002 follows the zero-order reaction ${ }^{35}$. The results from Wang et al. showed that the degradation of Reactive Black 5 by Bacillus sp. YZU1 approximates the first-order reaction ${ }^{13}$. Reactive Orange 13 degraded by $A$ faecalis PMS-1 was also well described by the first-order model ${ }^{15}$.

In this work, the degradation decreases with the increase in initial Acid Scarlet 3R concentration. As shown in Table 4, the correlation coefficients $\left(R^{2}\right)$ were in the range of $0.855-0.952$, and the first-order reaction model approximates the degradation process of Acid Scarlet 3R.

Furthermore, data also revealed that the initial dye concentration significantly affected the degradation rate, and the highest degradation rate was observed at the initial stage $(0-4 \mathrm{~h})$ in dye concentrations from 100 to $200 \mathrm{mg} \mathrm{L}^{-1}$, while that was determined at $8 \mathrm{~h}$ when more dye $\left(>400 \mathrm{mg} \mathrm{L}^{-1}\right)$ was added.



Fig. 5 - Model fitting for A. faecalis LJ-3 in degradation of Acid Scarlet 3R

Table 4 -Rate constants of degradation experiments with respect to dye concentration

\begin{tabular}{l|c|c|c|c|c|c}
\hline & \multicolumn{6}{|c}{ Concentration $\left(\mathrm{mg} \mathrm{L}^{-1}\right)$} \\
\cline { 2 - 7 } & 100 & 200 & 500 & 1000 & 1500 & 2000 \\
\hline$k_{0}\left(\mathrm{mg} \mathrm{L}^{-1} \mathrm{~h}^{-1}\right)$ & 5.667 & 12.42 & 34.49 & 68.83 & 71.62 & 69.19 \\
$R^{2}$ & 0.704 & 0.796 & 0.877 & 0.938 & 0.968 & 0.955 \\
$k_{1}\left(\mathrm{~h}^{-1}\right)$ & 0.297 & 0.343 & 0.355 & 0.288 & 0.080 & 0.047 \\
$R^{2}$ & 0.855 & 0.911 & 0.952 & 0.858 & 0.948 & 0.937 \\
$k_{2}\left(\mathrm{~L} \mathrm{mg}^{-1} \mathrm{~h}^{-1}\right)$ & 0.057 & 0.045 & 0.024 & 0.006 & 0.0001 & 0.00003 \\
$R^{2}$ & 0.921 & 0.883 & 0.628 & 0.524 & 0.853 & 0.904 \\
\hline
\end{tabular}


With the use of Origin 8.0 software, the degradation kinetics parameters and correlation coefficient were calculated. Previous works showed that Haldane equation displayed well the azo dye degradation of Bacillus sp. YZU1, while MichaelisMenten equation fits well the degradation process of $A$. faecalis PMS- $1^{13,15}$. In this work, the experimental data fitted well with Michaelis-Menten model (adj. $R^{2}=0.934$, Fig. 5), and the $K_{\mathrm{s}}$ and $V$ values were $1193.23 \mathrm{mg} \mathrm{L}^{-1}$ and $115.90 \mathrm{mg} \mathrm{L}^{-1} \mathrm{~h}^{-1}$, respectively.

\section{Conclusions}

In summary, $A$. faecalis LJ-3 has excellent ability to degrade Acid Scarlet 3R under a broad range of $\mathrm{pH}$, temperature, and initial dye concentrations, and can tolerate high salinity. The enzyme and UVvis spectroscopy analysis indicated that the strain degrades Acid Scarlet 3R by enzyme reaction, not simply by physical surface adsorption. The kinetics study showed that the degradation of Acid Scarlet 3R by $A$. faecalis LJ-3 approximates first-order reaction. Michaelis-Menten kinetics is suitable to fit the relationship between degradation rate and initial dye concentration, and $V_{\max }$ and $K_{\mathrm{s}}$ were found to be $115.90 \mathrm{mg} \mathrm{L}^{-1} \mathrm{~h}^{-1}$ and $1193.23 \mathrm{mg} \mathrm{L}^{-1}$, respectively. Furthermore, A. faecalis LJ-3 displays high degradation efficiency of various azo dyes used in the textile industries. It can be concluded that $A$. faecalis LJ-3 possesses practical application potential in biological treatment of industrial effluents containing various azo dyes.

\section{ACKNOWLEDGEMENTS}

The authors are sincerely thankful to the Wenzhou Science and Technology Bureau, China (Project grant No.W20170009).

\section{References}

1. Noorhosseini, S. A., Allahyari, M. S., Damalas, C. A., Moghaddam, S. S., Public environmental awareness of water pollution from urban growth: The case of Zarjub and Goharrud rivers in Rasht, Iran, Sci. Total Environ. 599-600 (2017) 2019.

doi: https://doi.org/10.1016/j.scitotenv.2017.05.128

2. Franciscon, E., Zille, A., Fantinatti-Garboggini, F., Silva, I. S., Cavaco-Paulo, A., Durrant, L. R., Microaerophilic-aerobic sequential decolourization/biodegradation of textile azo dyes by a facultative Klebsiella sp. strain VN-31, Process Biochem. 44 (2009) 446.

doi: https://doi.org/10.1016/j.procbio.2008.12.009

3. dos Santos, A. B., Cervantes, F. J., van Lier, J. B., Review paper on current technologies for decolourisation of textile wastewaters: Perspectives for anaerobic biotechnology, Bioresour. Technol. 98 (2007) 2369. doi: https://doi.org/10.1016/j.biortech.2006.11.013
4. Vikrant, K., Giri, B. S., Raza, N., Roy, K., Kim, K. H., Rai, B. N., Singh, R. S., Recent advancements in bioremediation of dye: Current status and challenges, Bioresour. Technol. 253 (2018) 355.

doi: https://doi.org/10.1016/j.biortech.2018.01.029

5. Kučić, D., Kopčić, N., Briški, F., Biodegradation of agro-industrial waste, Chem. Biochem. Eng. Q. 31 (2017) 369. doi: https://doi.org/10.15255/CABEQ.2017.1116

6. Huang, G., Wang, W., Liu, G., Simultaneous chromate reduction and azo dye decolourization by Lactobacillus paracase CL1107 isolated from deep sea sediment, J. Environ. Manage. 157 (2015) 297. doi: https://doi.org/10.1016/j.jenvman.2015.04.031

7. Tan, L., He, M., Song, L., Fu, X., Shi, S., Aerobic decolorization, degradation and detoxification of azo dyes by a newly isolated salt-tolerant yeast Scheffersomyces spartinae TLHS-SF1, Bioresour. Technol. 203 (2016) 287. doi: https://doi.org/10.1016/j.biortech.2015.12.058

8. Holkar, C. R., Jadhav, A. J., Pinjari, D. V., Mahamuni, N. M., Pandit, A. B., A critical review on textile wastewater treatments: Possible approaches, J. Environ. Manage. 182 (2016) 351.

doi: https://doi.org/10.1016/j.jenvman.2016.07.090

9. Khan, Z., Jain, K., Soni, A., Madamwar, D., Microaerophilic degradation of sulphonated azo dye-Reactive Red 195 by bacterial consortium AR1 through co-metabolism, Int. Biodeterior. Biodegrad. 94 (2014) 167. doi: https://doi.org/10.1016/j.ibiod.2014.07.002

10. Chen, Y., Feng, L., Li, H., Wang, Y., Chen, G., Zhang, Q., Biodegradation and detoxification of Direct Black G textile dye by a newly isolated thermophilic microflora, Bioresour. Technol. 250 (2018) 650. doi: https://doi.org/10.1016/j.biortech.2017.11.092

11. Garg, S. K., Tripathi, M., Singh, S. K., Tiwari, J. K., Biodecolorization of textile dye effluent by Pseudomonas putida SKG-1 (MTCC 10510) under the conditions optimized for monoazo dye orange II color removal in simulated minimal salt medium, Int. Biodeterior. Biodegrad. 74 (2012) 24. doi: https://doi.org/10.1016/j.ibiod.2012.07.007

12. Guadie, A., Tizazu, S., Melese, M., Guo W., Ngo, H. H., Xia, $S$., Biodecolorization of textile azo dye using Bacillus sp. strain $\mathrm{CH} 12$ isolated from alkaline lake, Biotechnol. Rep. 15 (2017) 92. doi: https://doi.org/10.1016/j.btre.2017.06.007

13. Wang, Z. W., Liang, J. S., Liang, Y., Decolorization of Reactive Black 5 by a newly isolated bacterium Bacillus sp. YZU1, Int. Biodeterior. Biodegrad. 76 (2013) 41. doi: https://doi.org/10.1016/j.ibiod.2012.06.023

14. Du, L. N., Li, G., Zhao, Y. H., Xu, H. K., Wang, Y., Zhou, Y., Wang, L., Efficient metabolism of the azo dye methyl orange by Aeromonas sp. strain DH-6: Characteristics and partial mechanism, Int. Biodeterior. Biodegrad. 105 (2015) 66. doi: https://doi.org/10.1016/j.ibiod.2015.08.019

15. Shah, P. D., Dave, S. R., Rao, M. S., Enzymatic degradation of textile dye Reactive Orange 13 by newly isolated bacterial strain Alcaligenes faecalis PMS-1, Int. Biodeterior. Biodegrad. 69 (2012) 41. doi: https://doi.org/10.1016/j.ibiod.2012.01.002

16. Bilal, M., Asgher, M., Enhanced catalytic potentiality of Ganoderma lucidum IBL-05 manganese peroxidase immobilized on sol-gel matrix, J. Mol. Catal. B: Enzym. 128 (2016) 82. doi: https://doi.org/10.1016/j.molcatb.2016.03.013 
17. Lowry, O. H., Rosebrough, N. J., Farr, A. L., Randall, R. J., Protein measurement with the Folin phenol reagent, J. Biol Chem. 193 (1951) 265.

18. Kong, L., Zhu, S., Zhu, L., Xie, H., Su, K., Yan, T., Wang, J., Wang, J., Wang, F., Sun, F., Biodegradation of organochlorine pesticide endosulfan by bacterial strain Alcaligenes faecalis JBW4, J. Environ. Sci. 25 (2013) 2257 doi: https://doi.org/10.1016/S1001-0742(12)60288-5

19. Zhao, W. Wang, C., Xu, L., Zhao, C., Liang, H., Qiu, L., Biodegradation of nicosulfuron by a novel Alcaligenes faecalis strain ZWS11, J. Environ. Sci. 35 (2015) 151. doi: https://doi.org/10.1016/j.jes.2015.03.022

20. Zhang, H. H., Wang, Y., Zhao, C., Wang, J., Zhang, X. L., Biodegradation of ochratoxin A by Alcaligenes faecalis isolated from soil, J. Appl. Microbiol. 123 (2017) 661. doi: https://doi.org/10.1111/jam.13537

21. Kalyani, D. C., Telke, A. A., Dhanve, R. S., Jadhav, J. P., Ecofriendly biodegradation and detoxification of Reactive Red 2 textile dye by newly isolated Pseudomonas sp. SUK1, J. Hazard. Mater. 163 (2009) 735. doi: https://doi.org/10.1016/j.jhazmat.2008.07.020

22. Saratale, R. G., Saratale, G. D., Chang, J. S., Govindwar, $S$. $P$., Ecofriendly degradation of sulfonated diazo dye C.I. Reactive Green 19A using Micrococcus glutamicus NCIM2168, Bioresour. Technol. 110 (2009) 3897. doi: https://doi.org/10.1016/j.biortech.2009.03.051

23. Saratale, R. G., Saratale, G. D., Chang, J. S., Govindwar, $S$. P., Bacterial decolorization and degradation of azo dyes: A review, J. Taiwan Inst. Chem. Eng. 42 (2011) 138. doi: https://doi.org/10.1016/j.jtice.2010.06.006

24. Jain, K., Shah, V., Chapla, D., Madamwar, D., Decolorization and degradation of azo dye - Reactive Violet 5R by an acclimatized indigenous bacterial mixed cultures-SB4 isolated from anthropogenic dye contaminated soil, J. Hazard. Mater. 213-214 (2012) 378. doi: https://doi.org/10.1016/j.jhazmat.2012.02.010

25. Mathew, S., Madamwar, D., Decolorization of ranocid fast blue dye by bacterial consortium SV5, Appl. Biochem. Biotechnol. 118 (2004) 371. doi: https://doi.org/10.1385/ABAB:118:1-3:371

26. Imran, M., Arshad, M., Negm, F., Khalid, A., Shaharoona B., Hussain, S., Nadeem, S. M., Crowley, D. E., Yeast extract promotes decolorization of azo dyes by stimulating azoreductase activity in Shewanella sp. strain IFN4, Ecotoxicol. Environ. Saf. 124 (2016) 42. doi: https://doi.org/10.1016/j.ecoenv.2015.09.041
27. Pearce, C. I., Lloyd, J. R., Guthrie, J. T., The removal of colour from textile wastewater using whole bacterial cells: A review, Dyes Pigments 58 (2003) 179. doi: https://doi.org/10.1016/S0143-7208(03)00064-0

28. Gopinath, K. P., Kathiravan, M. N., Srinivasan, R., Sankaranarayanan, $S$., Evaluation and elimination of inhibitory effects of salts and heavy metal ions on biodegradation of Congo red by Pseudomonas sp. mutant, Bioresour. Technol. 102 (2011) 3687. doi: https://doi.org/10.1016/j.biortech.2010.11.072

29. Khalid, A., Kausar, F., Arshad, M., Mahmood, T., Ahmed, I., Accelerated decolorization of reactive azo dyes under saline conditions by bacteria isolated from Arabian seawater sediment, Appl. Microbiol. Biotechnol. 96 (2012) 1599. doi: https://doi.org/10.1007/s00253-012-3877-7

30. Kurade, M. B., Waghmode, T. R., Khandare, R. V., Jeon, B. H., Govindwar, S. P., Biodegradation and detoxification of textile dye Disperse Red 54 by Brevibacillus laterosporus and determination of its metabolic fate, J. Biosci. Bioeng. 121 (2016) 442. doi: https://doi.org/10.1016/j.jbiosc.2015.08.014

31. Singh, R. L., Singh, P. K., Singh, R. P., Enzymatic decolorization and degradation of azo dyes-A review. Int. Biodeterior. Biodegrad. 104 (2015) 21. doi: https://doi.org/10.1016/j.ibiod.2015.04.027

32. Zhao, M., Sun, P. F., Du, L. N., Wang, G., Jia, X. M., Zhao, $Y$. H., Biodegradation of methyl red by Bacillus sp. strain UN2: Decolorization capacity, metabolites characterization, and enzyme analysis, Environ. Sci. Pollut. Res. 21 (2014) 6136. doi: https://doi.org/10.1007/s11356-014-2579-3

33. Pathak, H., Soni, D., Chauhan, K., Evaluation of in vitro efficacy for decolorization and degradation of commercial azo dye RB-B by Morganella sp. HK-1 isolated from dye contaminated industrial landfill, Chemosphere 105 (2014) 126. doi: https://doi.org/10.1016/j.chemosphere.2014.01.004

34. Wang, H., Zheng, X. W., Su, J. Q., Tian, Y., Xiong, X. J., Zheng, T. L., Biological decolorization of the reactive dyes Reactive Black 5 by a novel isolated bacterial strain Enterobacter sp. EC3, J. Hazard. Mater. 171 (2009) 654. doi: https://doi.org/10.1016/j.jhazmat.2009.06.050

35. Sudha, M., Bakiyaraj, G., Saranya, A., Sivakumar, N., Selvakumar, G., Prospective assessment of the Enterobacter aerogenes PP002 in decolorization and degradation of azo dyes DB 71 and DG 28, J. Environ. Chem. Eng. 6 (2018) 95. doi: https://doi.org/10.1016/j.jece.2017.11.050 